\title{
Curriculum Innovation: Should ESP be Given as an Elective or Compulsory Course? (A Case in Indonesia)
}

\author{
Dwi Poedjiastutie, \& Cahya Intan Syafinaz \\ Universitas Muhammadiyah Malang \\ E-mail: dwi_p@umm.ac.id; cahyaintansyafinaz@gmail.com
}

\begin{abstract}
How to cite (in APA Style): Poedjiastutie, D., \& Syafinaz, C.I. (2020). Curriculum innovation: should ESP be given as an elective or compulsory course? (A case in Indonesia). Jumal Pendidikan Bahasa dan Sastra, Vol. 20(2), 221-232. doi:https://doi.org/10.17509/bs_jpbsp.v20i2.33062
\end{abstract}

Article History: (Received: 18 July 2020, Revised: 20 Aug 2020, Accepted: 1 Sept 2020)

Journal homepage: http://ejournal.upi.edu./index.php/BS_JPBSP

\begin{abstract}
English Language Education Department (ELED) at the University of Muhammadiyah Malang (UMM) is educational department that has objectives to prepare competent future English teachers. Several elective courses are offered for sixth-semester students in order to equip its graduates with the skills that students may choose amongst Translation, Bussiness English, English for Young Learners, and American Studies. This issues are interesting especially the need for the ESP as an elective course arises from the inadequacy of ESP teachers' professional skills, training, and experiences that may cause teachers lacking of ESP teaching capacity.The researcher used descriptive qualitative research in order to get in depth and detail information in the form of a description about the reasons of ELED UMM not providing ESP as an elective course. Three researcher have interviewed the Director of Language Center (LC) UMM, ESP lecturer, and Secretary of ELED UMM. The research finding showed that ELED UMM focuses on producing the English teachers for secondary education not at a tertiary level. To respond on the needs of professional ESP teachers, ELED UMM offers TEFL (Teaching English as Foreign Language) course as a compulsory course which ESP materials have been integrated.
\end{abstract}

Keywords: Elective Course; English for Specific Purposes; Indonesian EFL context; curriculum design

\section{Inovasi Kurikulum: Haruskah ESP Diberikan sebagai Mata Kuliah Pilihan atau Wajib? (Sebuah Kasus di Indonesia)}

\begin{abstract}
Abstrak: Jurusan Pendidikan Bahasa Inggris (JPBI) Universitas Muhammadiyah Malang (UMM) merupakan jurusan pendidikan memiliki tujuan untuk mempersiapkan calon guru Bahasa Inggris yang berkompeten. Beberapa mata kuliah pilihan ditawarkan kepada mahasiswa semester enam untuk membekali lulusannya dengan keterampilan yang dapat dipilih siswa antara Terjemahan, Bahasa Inggris Bisnis, Bahasa Inggris untuk Pelajar Muda, dan Studi Amerika. Hal ini menarik terutama kebutuhan akan ESP sebagai mata kuliah elektif yang timbul dari kurangnya keterampilan profesional, pelatihan, dan pengalaman guru ESP yang dapat menyebabkan kurangnya kapasitas mengajar guru ESP. Peneliti menggunakan penelitian kualitatif deskriptif untuk masuk informasi mendalam dan detail berupa uraian tentang alasan JPBI UMM tidak menyelenggarakan mata kuliah pilihan ESP. Tiga peneliti telah mewawancarai Direktur Language Center (LC) UMM, Dosen ESP, dan Sekretaris ELED UMM. Hasil penelitian menunjukkan bahwa JPBI UMM berfokus pada menghasilkan guru bahasa Inggris untuk pendidikan menengah bukan pada jenjang perguruan tinggi. Untuk menjawab kebutuhan tenaga pengajar ESP yang profesional, JPBI UMM menawarkan mata kuliah TEFL (Pengajaran Bahasa Inggris sebagai Bahasa Asing) sebagai mata kuliah wajib yang materi ESP telah terintegrasi.
\end{abstract}

Kata kunci: Mata Kuliah Pilihan; Bahasa Inggris untuk Tujuan Khusus; konteks Bahasa Inggris EFL; desain kurikulum 


\section{INTRODUCTION}

The elective course is an optional course generally regulated by certain institutions to achieve certain objectives. Eva and Vendula (2017) defined elective course as the practical subject which the students can opt. The elective course is assured to have beneficial roles both for the students and the institutions. The students are increasingly motivated to learn due to the elective course such as enriching their professional portfolio that will be fruitful for their future careers. It is supported by Movchan and Zarishniak (2017) who stated that the elective course is important in building students' professional and personal development.

Many academic institutions provide elective courses as the effort of branching curriculum to maximize the students' potentiality. Brown et al. (2008) revealed that providing elective course is a strategic plan to meet the objectives of academic course for the $21^{\text {st }}$ century. Elective courses have the notable role in developing students' skill by presenting theoritical subjects to understand the context and the practical subjects to enrich students' portfolio. By taking an elective course, students are more interested and motivated in learning because they believed that elective course will enable them to achieve their goals and shape their professional image. (Movchan and Zarishniak, 2017).

It would be such a challenging homework for the educators in many institutions to provide the best elective courses to equip the students with various of skills and competences in order to face the stringency of $21^{\text {st }}$ century since the design of elective course should reflect students' needs and preferences and should provide the student with a well-rounded, quality education. (Eva and Vendula, 2017).

One of elective course that is offered by many institutions or universities especially in Indonesia is English for Specific Purposes (ESP) since ESP course is believed to meet students' future career needs or to meet the global trend as well. Nevertheless, studies have found several current issues that still be problematic in ESP teaching. Those issues are related to the teachers, course designs, course objectives, course materials, and assessments (Kusni, 2013). The teachers issue is derived from the lack of institutions that produce the specific English lecturers such as ESP, the lack of opportunities that ESP lecturers have in developing their teaching quality such as ESP workshop and seminar, and the overloaded teaching responsibility that ESP lecturers have to do. The course design issue comes from the absence of need analysis in ESP teaching. This condition affects the objectives, the course materials, and the assessment at the same time. It makes the ESP in Indonesia lost its true self.

The major issue that needs to be highlighted is no specific institutions or universities in Indonesia which are officially responsible to produce ESP specialists and provide ESP teacher development programs such as training, workshop, and seminar. As the result, the lack of capability and proficiency in designing and teaching ESP courses has been found (Yoestara, 2017). It is also revealed by Muhrofi-Gunadi (2016) that most of ESP lecturers in Indonesia are not adequately trained to teach ESP even though ESP teachers at any educational level have several important roles such as teachers, course designers, researchers, collaborators, and evaluators (Dudley-Evans and St. John, 1997). In other words, most of ESP teachers at any educational level have never been trained specifically to handle ESP classes so they withdraw themselves teaching ESP and back to old teaching principle of General Purposes (EGP) (Basturkmen, 2010).

This issues are interesting to be considered by English Language Education Department (ELED) at University of Muhammadiyah Malang (UMM) to provide an elective course that would produce the qualified future ESP teachers since the demand of professional ESP teachers has increased especially within the institution itself. The need for this elective course arises from the inadequacy of ESP teachers' professional skills, training, and experiences 
that may cause ESP teachers were lacking of ESP teaching capacity (Astika, 1999). Astika further suggests that at least one university in Indonesia offers ESP education program for producing ESP specialists.

\section{The ESP Pedagogy}

English for Specific Purposes (ESP) is an approach of language teaching which the content and method in teaching are adjusted based on the learning reason (Hutchinson \& Waters, 1987). The students from various departments who intend to learn English is supposed to be given English insights such as vocabularies related to their field of study. Ahmed (2014) defined ESP as the way of teaching or learning English for specialized subjects with some specific vocational and educational purposes. ESP is expected to develop students' communicative skills such as how to interact to the guests for students from Hospitality Department. For educational purposes, ESP is expected to develop students' skills in reading and even writing literatures.

Therefore, in teaching ESP, the lecturers are expected to consider the learners' needs in learning English in order to meet the learning purposes. Robinson (1991) argued that ESP is an effortby concerning education, training, and practice and reflecting language, pedagogy, and students' specialist area of interest.

ESP lecturers are suggested to understand the theoritical and practical terms in teaching ESP regarding to students' need. Richards and Rodger (2001) agreed that ESP is a movement that seeks to serve the language learners' needs in order to perform specific roles and to acquire content realworld skills. The specific roles and the realworld skills imply the involved of English skills in the students' disciplines, occupations, and activities.

Falaus (2016) stated that ESP is presently taught in universities all over the world with the purpose of preparing future specialists in various fields of activity. Brunton (2009) highlighted that ESP has increased over the decades as a result of market forces. It is also added that it is quite challenging to design and implement a successful ESP program. Teachers have the obligation to deal with those challenges and solve it in order to achieve the objectives of teaching and learning process in ESP. Teachers also have to know the strategy in teaching ESP and distinguish between ESP and English for General Purposes (EGP). The differences between ESP and EGP are still debating by some experts. However, Widdowson (1983) established the distinctive features of ESP and EGP. First, the focus of ESP is on training. Second, English in ESP is intended to be used in specific vocational contexts, so that the selection of the appropriate content is easier. Third, the content in the syllabus have to be relevant to the vocational context. Fourth, the aim of ESP creates a restricted English competence. While the focus of EGP is on education and the course content of EGP is more difficult to select since the learners' future needs are impossible to predict.

McDonough in Larouz and Kerouad (2016) distinguished the difference between ESP and EGP in the context of the teaching approach, ESP lecturers have to consider their students' needs (needs analysis) before they construct or design the materials then serve it to the students, unlike EGP lecturers that have the 'cooked' materials without considering their students' needs. In other words, ESP is likely described as a bottom-up approach which the lecturers start from the students' need before considering course design, evaluation and other issues, while EGP is likely described as a top-down approach which the lecturers do not need to consider such issues as ESP lecturers do.

What distiguishes ESP from EGP is the purpose and the implementation. The purpose of ESP is more practical than EGP. ESP is mostly centered on training to equip students with specific language skills for their specific needs and hopefully it can be applied directly for their practical use. Meanwhile EGP is aimed to educational purposes to develop a general capacity of language use and hopefully it can be used in practical later.In regards to the 
implementation, ESP should be based on an needs analysis (NA) to determine which language skills are most needed by the students and the syllabus is designed accordingly. In other words, the starting point for curriculum development of ESP is an analysis of students' needs rather than a linguistic analysis such in EGP.

Therefore, it seems like teaching ESP is more complicated than teaching EGP especially in designing the course which the teachers should take a look to the need analysis. Hutchinson and Waters (1987) argued that ESP teachers should be ready to ask and gather the information based on several questions.
The several questions are formulated as follows: (1) Why do students need to learn?, (2) Who is going to take part in this process? Is it teachers, students, experts in the field or etc?, (3) Where is the learning process going to take place? Does the location provide any potential or impose limitations?, (4) When is it set to take place? Is there time limit to be taken into consideration?, (5) What does the students need to learn? What aspects of the language would be more appropriate under the given circumstances?, and (6) How will the learning be achieved? What theoretical background will be chosen to fuel the methodology that is meant to be used?

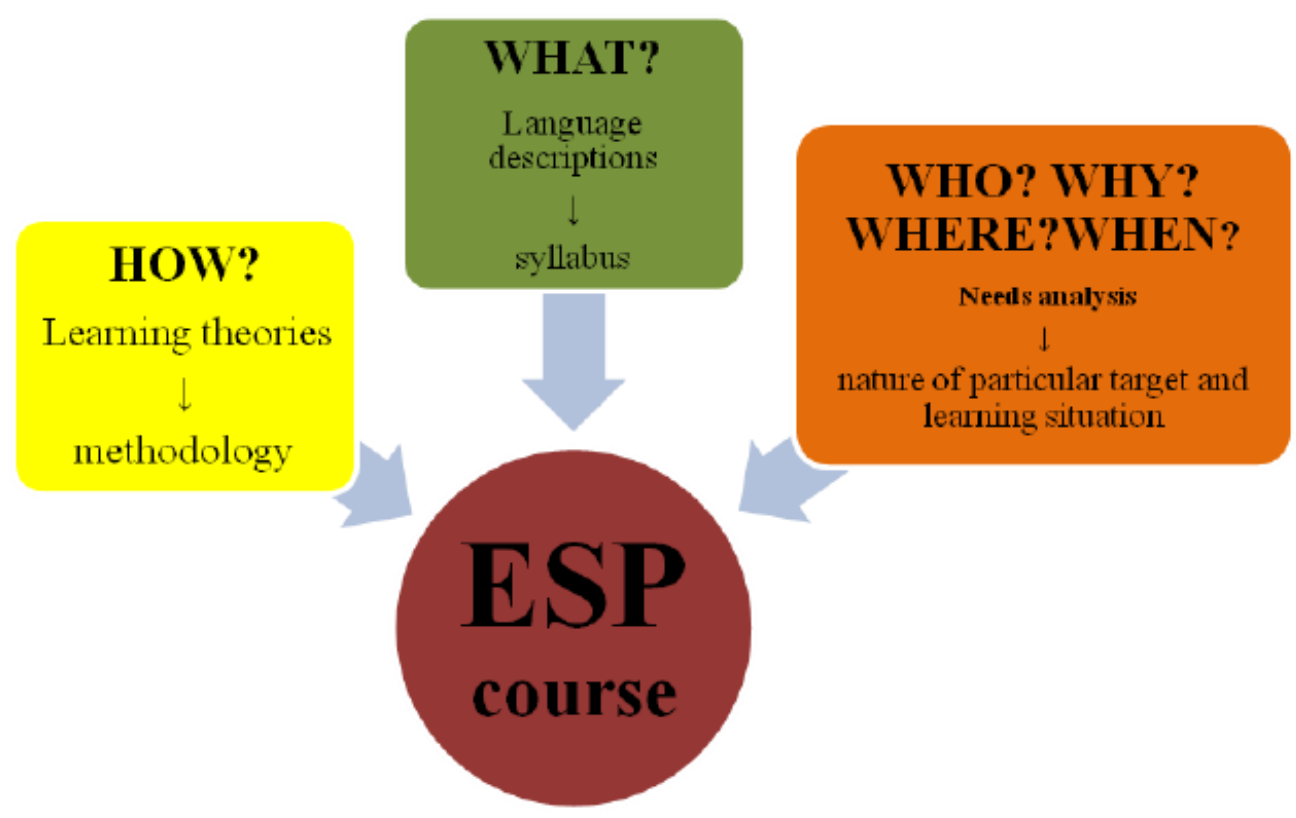

Figure 2.1: The Affecting Factors of ESP Course Design

(Hutchinson \& Waters, 1987)

Moreover, Morena (2014) distinguished the difference between ESP and EGP in the use of 'team teaching'. ESP is widely open to team teaching while EGP is hardly open to team teaching. ESP class is widely open to team teaching if an ESP teacher lacks the technical knowledge, for instance in engineering class, the ESP instructor might invites the asisstance from engineering faculty who can provide the technical knowledge to set up the simulation. In this case, the roles of ESP instructorare to make sure that each student is required to take part in the communicative task, to monitor each students' performance, and to provide corrective feedback for the students.

Therefore, it can be said that teaching ESP poses a lot of challenges than teaching EGP. ESP teachers at any educational level should be ready to face those challenges such as focusing on the students' specific needs to acquire a set of professional skills and focusing more on language in context. Furthermore, ESP and EGP can not be separated to each other, it is because in workplaces situation students will not only need ESP but also they still 
need EGP for instance for their daily life communication. It means that both of them; ESP and EGP are complement each other.

\section{The Context of the Study}

The Language Centre (LC) at UMM was first established in 1993. How this was initiated, the way it was founded at the beginning, and the way the program was promoted to the students at first is not documented. However, it appears that the English program that was offered at that time was similar to that of many others.

A year later in 1994, although still dominated by ELED UMM students, the number of participants at the LC was growing. To speed the development and status of English on campus, a 'revolutionary' rather than 'evolutionary' step was taken (Crystal, 2003). This was done through the formal recognition of the centre. In turn, this enabled the university to create and project an international profile. To achieve these goals, the following mission statement was developed for the LC.

a. Conducting quality English for Specific Purposes (ESP) program for students of UMM;

b. Providing quality English training for LC staff and UMM staff to be able to compete at both a national and international level;

c. Providing quality English teaching training for LC staff to produce professional, creative and skilful ESP instructors; and,

d. Building continuous cooperation in and outside the university to develop English education and training (Language Centre Team, 2002).

Translating these goals into practice led to the establishment of two different English programs to satisfy the needs of two main groups at UMM. The first is the English program that targets the students of this university and is conducted under the auspices of English for Specific Purposes (ESP). Staff members at LC also perform roles such as writing teaching resource materials, being test administrators and providing translation services. The second program targeted staff at UMM and is run in cooperation with the IALF.

English for Specific Purpose (ESP) is the LC program for all the freshmen enrolled at UMM. During the first year (two semesters) of their study, students in both the English and non-English Departments take different ESP courses depending on their majors. For example, students from the Mathematics Department study English for mathematics purposes. Thus, the ESP program provides English skill development so that students can read and comprehend English text books, journals, and articles in their disciplines. In addition, by undertaking this course, students build their spoken and written English communication skills.

Teachers at the LC are either fulltime contract teachers or part-time teachers. Full-time teachers are recruited from the pool of ELED UMM graduates every semester and given a maximum three year contract. It is agreed by Ozden in Ulusoy et al. (2012) who stated that in improving the quality of education, educational institutions are prominent to reconstruct the education system to make its programs more compatible with the changing needs, expectations, and social changes. Therefore, since the previous researches only studied about elective course from the students' perspectives and since ELED UMM only provided four elective courses for the 6thsemester students which had not to equip the graduates to be proficient ESP teachers yet, the researcher decided to find out the reasons of ELED UMM for not providing ESP as an elective course to prepare the students become adequate ESP teachers.

\section{METHODS}

Looking at the emergent themes was utilized to get detail information. Ary, Jacobs, and Sorensen (2010) who highlighted that the results of qualitative research are rich and comprehensive. Thus, the researcher is able to get more understanding of the research participants' experiences and perspectives. 
This statement likewise agreed by Sutton and Austin (2015) which qualitative research is able to help the researchers to access the thoughts and feelings of research participants. Merriam (2009) added that qualitative researchers are interested in understanding the meaning people have constructed, such as how people make sense of their world and the experiences they have in the world. Qualitative researcher is used to be familiarized with the data in the form of words instead of numerical data as well as in quantitative research. The ultimate goal of qualitative research is not the analysis of numerical data but the whole picture in the form of words and depth understanding of a certain phenomenon.

This research used purposive convenience sampling in choosing the research participants. According to Creswel and Plano Clark (2011), purposive sampling is choosing samples by involving and selecting the research participant that is proficient and well-informed with a certain phenomenon. Meanwhile, Ary et al. (2010) stated that convenience sampling is choosing a sample based on availability, time, location or ease of access. Therefore, this research used purposive convenience sampling because it depended on the research participants' proficiency and depended on the research participants' willingness to participate in the research.

The first participant was the representative of LC UMM, it was the Director of LC UMM. The researcher chose those research participants based on the research participants' criteria. The researcher believed that the director of LC UMM has detailed information related to the competencies of ESP teachers. The second participant was ESP lecturer at LC UMM who graduated from ELED UMM. The researcher believed that the ESP lecturer was able to give the suggestion to ELED UMM for equipping the future graduates with any teaching competencies. The third participant was the representative of ELED UMM, it was the Secretary of ELED UMM. The Secretary of ELED UMM was suitable to the problem of this research because as the management at ELED UMM who has its reason in regulating the policy that exists at ELED UMM. Hence, the curriculum developer was able to give the depth information related to the reasons of ELED UMM for not providing ESP as an elective course.

A semi-structured interview was employed in order to give more flexibility to the research participants in responding to the questions and give the opportunity to the researcher to expand more the information. Edwards and Holland (2013) stated that the semi-structured interview allows more space for research participants to answer by their own. Alshenqeeti (2014) pointed out that semi structured interview provides the opportunity for the researcher to probe and expand the research participants' responses.

\section{RESULTS AND DISCUSSION}

\section{The Challenges without ESP as an Elective Course \\ Challenge 1 (Insufficient ESP trainings)}

English for Specific Purposes (ESP) is the English that would be necessary for future graduates especially those who are from the undergraduate program to answer their future career opportunities.

The future scientists would need English to write their research reports so it can be published for international readership. The future customer service in bank would need English to speak with the customers. The future tour guides would need English to speak with native speakers who visit several tourism places. The future graduates who intend to go abroad to get their master's degree would likewise need English. Hence, the English at the tertiary level is supposed to be a specific one based on the students' needs and purposes. It was departing from the results of interview session as follow:

$$
\begin{aligned}
& \text {...the real ESP or ESP } 100 \% \text { is like we } \\
& \text { bave to teach the future bartenders, the future } \\
& \text { flight attendants, and so forth. (LC Director) }
\end{aligned}
$$


Meanwhile in this context, delivering ESP subject to the students is required proficient English teachers that have a specialty in ESP teaching. It indicated the importance of ESP is not only in the aspect of how the students acquire the subject but also in the aspect of how the students transfer the subject, so their English would be fruitful. It could be seen from the statement of research participant:

...there will be more job vacancies as ESP teachers or lecturers later...(ESP Lecturer).

Therefore, English that should be taught at the tertiary level is supposed to based on students' purposes and future career opportunities. Furthermore, to achieve ESP's objectives it is required ESP's experts that would deliver such appropriate ESP materials.

In ESP at LC UMM, speaking skills are expected to enhance students' communicative skills with the English topics that still in the scope of their disciplines. Listening skills are expected to develop students' capability in receiving and conceiving English voices such as dialogue, monologue, news, and so on that fit with their disciplines. Reading skills are expected to make the students be able to read and comprehend international references such as international journals that will be beneficial in supporting their field of study. As well as writing skills are expected to improve students' writing skills for instance in writing an application letter, writing an internship report, writing research journals, and all the things that suited their major field. However, the research participants admitted English that has been taught to the students in ESP class is not specific as it was supposed to be:

Basically teaching material is the same as general purposes but the topic is adjusted with students' major field (ESP Lecturer).

Those statements indicated the real identity of ESP that is supposed to give the specific English for students is not visible yet and English for General Purposes (EGP) materials are still used in ESP class.
Aside from developing students' English skills, LC UMM is also regulating the training program for ESP lecturers especially for newcomers who have contracted to teach ESP at LC UMM. This action is taken by The Director of LC UMM since most of the applicants are fresh graduates from Bachelor's Degree. This is asserted there is still any doubt from LC UMM employer to its employee since the new ESP lecturers are mostly fresh graduates from undergraduate programs and they have passed several recruitment steps.

Yes, we have training for the new ESP

lecturers. They have to join Microteaching training fully in one semester on each Saturday because we think that Microteaching is important for them as the preparation to be a good teacher (LC Director).

Even though the new ESP lecturers especially the graduates from ELED UMM have passed all those selections, they have to join the Microteaching training program as the additional activity.This program is aimed to improve their quality in teaching ESP by peer teaching method. Thus, there are no specific instructors or ESP experts that provide pedagogical principles of ESP teaching.give them tips on how to teach ESP properly since they only get feedback from their co-workers. It is reperesented on the research participant's statement:

So, they teach their colleagues then their colleagues will give such comments about their teaching such as their weaknesses and strengths (LC Director).

In short, the teaching quality of ESP lecturers at LC UMM still needs to be considered since the training is not supervised by the qualified ESP experts. It was supervised by their fellow friends instead. As a result, most of students complained the teaching quality of ESP lecturers at LC UMM. It can be seen at ESP lecturers' evaluation report as follow:

The thing that should be improved by the lecturer is the way to explain the materials. It 
is not supposed to be so fast.(Retrieved from Evaluation Report of Lecturer)

\section{Challenges 2 (The absence of Needs Analysis)}

The teaching ESP required proficient ESP teachers or experts since teaching ESP is different from teaching EGP. The difference between teaching ESP and EGP lies in the use of the need analysis (NA). Need analysis is a crucial part of teaching ESP since the teachers should know what English that their students need to master. The teachers are supposed to analyze students' background, purpose in studying English, choice in choosing the type of future occupation and workplaces, type of skill that needs to be developed, English preference learning style, target language level, and so forth.

Due to the absence of NA skill, the teachers failed to distinguish the strategy between teaching ESP and EGP. The lack of insight in teaching ESP frequently plunges ESP teachers to use EGP teaching strategies. It was departing from the research participant's statement:

...before we go through to the ESP, we have to set students' need analysis right? Sometimes because we do not know what ESP is then we fall back to EGP (ESP Lecturer)

It showed that ESP teachers especially at LC UMM, mostly faced the problems in opting teaching strategy between ESP and EGP. This condition can be caused by the unavailable chance and time for them to analyze the students' needs and decide the materials before they are going to teach. It is also due to the teachers' responsibility at LC UMM to teach several classes in different departments, as stated as follow:

It's quite difficult for me to teach English especially specific English for several classes because I only have to adjust the vocabulary and relate the materials that have set up by $L C$ to the topic. Finally, I switch to general English because I have no time to do the preparation (ESP Lecturer)
The number of classes with different disciplines areas that should be taught by ESP lecturers at LC UMM in one semester causes them less focus in teaching. The only thing that they can do to cope with those problems is teaching EGP and relying on the book that has been set up by LC UMM. It accordingly showed that the real identity of ESP at LC UMM disappear due to illprepared teachers

\section{Challenges 3 (The absence of collaborative teaching strategy)}

In addition, it would be great for ESP teachers to collaborate with subject lecturers from the various department in the ESP teaching process. For instance, an ESP lecturer may invite a lecturer from that department to discuss such as the teaching materials, vocabularies that are usually used in that department, and so on. In speaking class, if the topic is about "Food Festival", then a lecturer from the department is showing what kind of foods that would be great to be on display and the ESP lecturer would monitor how the students speak English and present the food in a communicative way to the festival visitors. This statement also showed the concern:

It will be better if there is a teaching team in LC UMM, so the lecturers will be divided into several teams, for instance, team for Teacher Training and Education Faculty, Law Faculty, Engineering Faculty, and so forth (ESP Lecturer)

Surprisingly, the problems are not only lied to the teachers but also the students. The students are deemed not ready enough to get ESP materials since ESP is given in the first and second-semester students. It is based on the interview result that stated as follow:

It will be better if it is tanght in the third or fifth semester because they have known that they are fit in their major so they will know what English they need, but if it is tanght in the first or second semester, sometimes they choose their major fields because of their mistakes or having forced by someone, that 
makes them get blank in English (ESP Lecturer)

It is appointed that few improvements should be done by ESP lecturers and management at LC UMM to invent the real ESP.

\section{Some Reasons for not providing ESP as an Elective Course Reason 1 (The Goals of ELED UMM)}

Besides having LC as the language center to improve the students' and teachers' English proficiency, English Department is a part of the institution to produce the graduates of English teachers. ELED UMM objectives is to prepare future English teachers to be capable in English teaching especially in teaching English for secondary level students. This was derived from the results of the interview session:

So, the focus of our department is to produce future graduates to be future teachers especially in the secondary level of education such as Junior and Senior High School (ELED Secretary)

This statement indicated that the curriculum of ELED UMM does not prepare the graduate to teach ESP. However, due to the existence of LC UMM and the needs of ESP instructors, many ELED UMM graduates were recruited to teach at the LC UMM. In other words, UMM graduates were not only prepared to teach at the secondary level but also the tertiary level of education. The absence of NA leads this chaotic situation. When the ELED UMM were accepted to the ESP teaching careers, they may not be able to function directly.

\section{Reason 2 (The lack of ESP experts and resources)}

Teaching Vocational English (TVE) as a part of ELED curriculum has been given since 2013. TVE was actually similar to ESP. However, the students only learnt TVE in one semester or 14 meetings altogether of ESP subjects' credits or recently known as TVE is only two credits.

...in the two credits courses, the students are tanght how to teach English for specific purposes starting from analyzing needs, then how they should decide or construct the materials based on the needs (ELED Secretary)

ELED UMM's students were also not equipped with ESP/TVE teaching skills since they were taught the theory of ESP teaching rather than given chance to practice directly how to teach ESP/TVE. This is in stark contrast with other elective subjects such as Bussiness English (BE), Translation, English for Young Learners (EYL), and American Studies (AS). Those elective courses offer an adequate timeframe for internship in companies so that students are expected to have sufficient employability skill when they apply for the similar position in the future. Since ESP/TVE is almost in many sectors of life, the resources and expertise in these areas were badly needed and this was not yet possessed by the ELED UMM.

...it would be huge and quite challenging for us to give the course to the students about how to teach English for instance, for teaching 50 different major fields because not everyone would teach all of those studies at least they would teach five major fields only (ELED Secretary)

... and because they will not teach English students only, but also Engineering students, Tourism students, etc, at least they get to know the principle of ESP teaching (ESP Lecturer)

\section{Reason 3 ESP have been included at TEFL subject}

Instead of making ESP/TVE as an elective course, ELED UMM regulates it as a compulsory course with the consideration that every student deserves to have the teaching skills. ELED UMM provides Teaching English as Foreign Language (TEFL) course to prepare the future teachers. It was departing from the research participant's statement:

....in the TEFL course, the students will get all the things about teaching that they have to know such as how to teach English for 
Young Learners (EYL), and even how to teach English for Specific Purposes (ESP/TVE) as well (ELED Secretary)

ELED UMM is aware of equipping the future graduates to obtain the teaching skills more fully by offering big amount of credits in the TEFL course; six credits for TEFL in theory and another six credits for TEFL in practice.

In a bachelor's degree, the students in the Faculty of Teacher Training and Education usually are given a Teaching strategy subject as the theory and Microteaching as the practical (LC Director)

The TEFL course is believed to be the solution for ELED UMM students to know the teaching circumstances.

Yes, I think it is more than enough to equip future graduates to teach proficiently because the credits for that course are quite big (ELED Secretary)

\section{CONCLUSION}

From the result of the research, it can be concluded that applying ESP is required several preparations. First, ESP teachers need to be familiarized with the core of ESP teaching skills such as analyzing the students' needs. The absence of need analysis derives the teachers lie back to teach EGP, so the natures of ESP are ignored. Besides, ESP teachers need to manage the overload work hours to minimize the lack of focus in teaching ESP. Joining workshops, seminars, and lecturers related to ESP issues can be done by ESP teachers to be wellprepared in teaching ESP.

In answering the hesitation and suggestion from LC UMM toward the teaching capability of ELED UMM graduates, ELED UMM has equipped the future graduates by providing a TEFL course with a big amount of credits for theoretical and practical. This course is intended to prepare future teachers to be familiarized with teaching matters such as teaching EYL, EGP, and especially ESP. Moreover, the teaching quality of ELED UMM graduates still can be considered by the secondary institutions to teach at Junior, Senior, and even Vocational High School.

Several suggestions can be given from the research to ELED UMM, LC UMM, and ELED UMM's students. First, ELED UMM is suggested to prepare the graduates in a balanced way both theoretical and practical so the future graduates will be ready to face the teaching professionalism demand, especially in ESP teaching. Likewise, it is suggested for ELED UMM to be more updated on the new teaching approaches to attract future graduates' motivation in improving their skills and quality development. In a nutshell, ELED UMM is expected to be not only focus to produce English teachers at secondary educational level but also at tertiary level. It would be great if ELED UMM decides to be one of the pioneers that have specialized in producing ESP specialists in Indonesia. Simultaneously, it would promote the quality of ELED UMM itself.

Second, the suggestion for LC UMM is addressed to the Director and the ESP lecturers. First, the Director of LC UMM is suggested to hire the applicants that have specialized in ESP teaching so there would be no more confusion in distinguishing the teaching strategy of ESP and EGP. Second, the Director of LC UMM is suggested to give a chance for ESP lecturers to analyze the students' needs to bring the true identity of ESP. Third, the Director of LC UMM is expected to offer workshops, training, and seminar with ESP experts outside of UMM to develop the quality of ESP teaching. Besides, ESP lecturers at LC UMM as well are suggested to collaborate with other lecturers from other departments so there would be no more misconceptions between English with the students' disciplines.

Third, ELED UMM students are suggested to develop their teaching skills by utilizing the courses that have been offered by the department. It is suggested for ELED UMM students to use the learning opportunity wisely by applying the theory that they have got into practical subjects. For instance, in the TEFL course, when they got a theory about need analysis, they 
are expected to analyze the students' needs when they are practicing to teach ESP.

\section{REFERENCES}

Ahmed, M. K. (2014). Issues in ESP (English for Specific Purposes). International Journal for Teachers of English, 4(1), 35-59.

Alshenqeeti, H. (2014). Interviewing as a data collection method: A critical review. English Linguistics Research, 3(1), 39-45. https://doi.org/10.5430/elr.v3n1p39

Ary, D., Jacobs, L. C., Sorensen, C., \& Razavieh, A. (2010). Introduction to research in education ( $\delta^{\text {th }} \quad$ ed.). Wadsworth: Matrix Productions, Inc.

Astika, G. (1999). The role of need analysis in English for Specific Purposes. TEFLIN Journal, $\quad$ 10(1), 31-47.

Basturkmen, H. (2010). Developing courses in English for specific purposes. England: Palgrave Macmillan.

Brown, B., Warren, N. S., Brehm, B., Breen, P., Bierschbach, J. L., Smith, R., Wall, A., \& Van Loon, R. A. (2008). The design and evaluation of an interprofessional elective course with a cultural competence component. Journal of Allied Health, 37(4), 316-337.

Brunton, M. (2009). An account of ESP with possible future directions. English for Specific Purposes, 8(24), 1-15.

Creswell, J.W. and Plano Clarck, V.L. (2011). Designing and conducting mixed methods research ( $2^{\text {nd }} \quad$ ed.). Los Angeles: Sage Publishing.

Crystal, D. (2003). English as a global language. Cambridge: Cambridge University Press.

Dudley-Evans, T., \& St. John, M. J. (1998). Developments in English for specific purposes. Cambridge: Cambridge University Press.

Edwards, R., \& Holland, J. (2013). What is qualitative interviewing? England: Bloomsburry Publishing.

Eva, K., \& Vendula, K. (2017). The factors influencing college students' choice of elective subjects. Journal of Competitiveness, 9(4), 40-49. https://doi.org/10.7441/joc.2017.04. $\underline{03}$

Falaus, A. (2016). The current challenges of teaching ESP.Innovative Ideas in Science.

$\underline{\text { https://doi.org/10.1088/1757- }}$

Hutchinson, T., \& Waters, A. (1987). English for specific purposes: A learning centered approach. Cambridge: Cambridge University Press

Kusni. (2013). Reformulating English for specific purposes (ESP) in Indonesia: Current issues and future prospects. Proceedings of ISELT FBS Universitas Negeri Padang, 36-48.

Language Center Team (2002). LC-UMM Statuta. Universitas Muhammadiyah Malang.

Larouz, M., \& Kerouad, S. (2016). Demystifying the disparity between ESP and EGP methodology.

ASELS Annual Conference Proceedings, Mohammed V University of Rabat, Morocco, (pp. 97-105).

Merriam, S. (2009). Qualitative research: A guide to design and implementation. San Fransisco: Jossey-Bass.

Morena, B. (2014). Teaching English for Specific Purposes and teacher training. European Scientific Journal, 10(2), 40-49.

Movchan, L., \& Zarishniak, I. (2017). The role of elective courses in students' professional development:

Foreign experience. Comparative Professional Pedagogy, 7(2), 20-26. https://doi.org/10.1515/rpp-2017$\underline{0018}$

Muhrofi-Gunadi, K. A. (2016). ESP practitioners' role and their ethnography: A case study of ESP practitioners at the Indonesian tertiary level. International Journal of Education, 9(1), 1-9.

Richards, J. C., \& Rodger, S. T. (2001). Approach and methods in language teaching. Cambridge: Cambridge University Press. 
Robinson, P. C. (1991). ESP today practitioners guide. New York: Prentice Hall.

Sutton, J., \& Austin, Z. (2015). Qualitative research: Data collection, analysis, and management. The Canadian Journal of Hospital Pharmacy, 68(3), 226231.

Ulusoy, Y. O., Dag, F., Fidan, D., Sahranc, U., Inan, B., \&Gullu, D. (2012). Student opinions about elective courses in changing education: The example of Kocaeli University Faculty of Education. Journal of Educational and Instructional Studies, 2(4), 135-142.

Widdowson, H. G. (1983). Learning purpose and language use. Oxford: Oxford University Press.

Yoestara, M. (2017). Looking into the process of teaching and learning English for Specific Purposes (ESP) at the university level in Indonesia: Problems and solutions. Jurnal Serambi Ilmu, 18(1), 18-24. 